\title{
Winter moisture content and frost-crack occurrence in oak trees (Quercus petraea Liebl. and Q. robur L.)
}

\author{
B. Cinotti \\ Station de Recherches sur la Qualité des Bois, INRA-CRF, Nancy, France
}

\section{Introduction}

Our research investigates the relations between the frost-crack occurrence in oaks and some physical and anatomical parameters of solid wood. The starting point of our interest in water in trees is the observation that frost-cracks occur with a higher frequency in trees growing on soils with high winter moisture content (Schirp, 1968). Also, severe stem contractions with freezing winter temperatures (greater than those arising from summer droughts, but equally dependent upon the moisture content) have been commonly observed (Hinckley et al., 1978). In this paper, we report our observations of winter moisture content variation in oak trees, using nondestructive sampling by increment cores, and relate it to frost-crack occurrence.

\section{Materials and Methods}

Increment cores were taken from 90 oak trees from 3 different forests in central and eastern France. Paired trees of similar diameter, as in our previous study (Cinotti, 1987), one frostcracked and one sound in close proximity to counteract the possible effects of differences in soil, were chosen.

An increment borer was used to take diametral cores in an approximate north-south direction. Cores were then kept in plastic tubes whose diameters were just sufficient for the core to enter. This prevented water loss from the cores.

In the laboratory, the increment core of each tree was divided into 6 pieces: central heartwood (rings from pith to the 15th), external heartwood (rings from the 16th ring up to the sapwood-heartwood limit) and sapwood from both the northern and southern sides of the bole. Each piece was immediately weighed while wet and then dried in an oven at $103^{\circ} \mathrm{C}$ for at least one day. A second weighing gave the dry weight and, by subtraction, the initial water weight. Moisture content (water weight divided by the weight of dry wood) is expressed as a percentage.

\section{Results}

Table I illustrates the variability of results from one forest to the other (even on cores bored at proximate dates), and for the same plot and on the same trees from one month to the next. However, the following general observations could be made: 1) winter moisture content in oak 
Table I. Moisture content (in \%) variations.

\begin{tabular}{|c|c|c|c|c|c|}
\hline & General mean & Sapwood & $\begin{array}{l}\text { Middle } \\
\text { heartwood }\end{array}$ & $\begin{array}{l}\text { Central } \\
\text { heartwood }\end{array}$ & \\
\hline \multicolumn{6}{|c|}{$\begin{array}{l}\text { Bellary } \\
\text { (Nière, Q. petraea Liebl.) }\end{array}$} \\
\hline January & 86.5 & 89.5 & 85.0 & $=84.9$ & $\star \star \star \star$ \\
\hline February & 83.1 & 85.8 & 81.7 & $=81.9$ & $\star \star * *$ \\
\hline March & 81.0 & 81.7 & $=81.1$ & $=80.1$ & NS \\
\hline \multicolumn{6}{|c|}{$\begin{array}{l}\text { Mouterhouse } \\
\text { (Moselle, Q. petraea Liebl.) }\end{array}$} \\
\hline March & 87.0 & 89.3 & 88.1 & 83.6 & $* \star \star$ \\
\hline $\begin{array}{l}\text { Vierzon } \\
\text { (Cher, Q. ro }\end{array}$ & \multicolumn{4}{|c|}{ (Cher, Q. robur L.) } & \\
\hline $\begin{array}{l}\text { February } \\
\text { March }\end{array}$ & $\begin{array}{l}94.2 \\
95.1\end{array}$ & $\begin{array}{r}99.8 \\
100.6\end{array}$ & $\begin{array}{l}96.2 \\
97.1\end{array}$ & $\begin{array}{l}86.5 \\
87.6\end{array}$ & 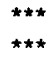 \\
\hline
\end{tabular}

The meaning of the = signs is that, among 3 moisture contents compared, only one is significantly different from the other two (NS: non significant, " significance threshold $5 \%,{ }^{* * *} 0.1 \%$ ).

Table II. Moisture content opposition.

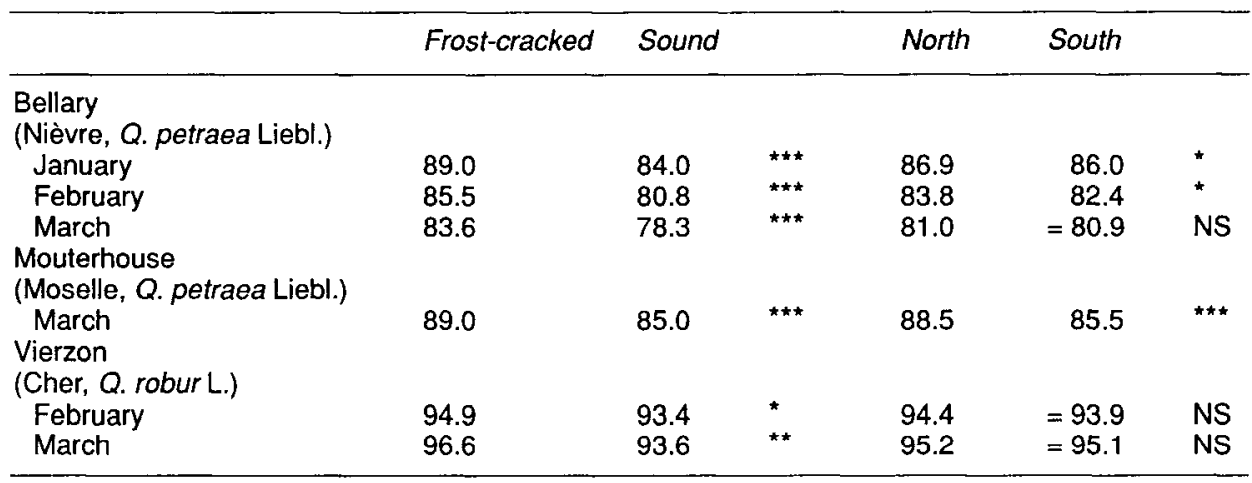

tree boles is from $60 \%$ to total saturation, i.e., in the range where wood freezing expansion counteracts more or less frostshrinkage (Schirp and Kübler, 1968; Kübler, 1983; Cinotti and Tahani, 1988); 2) the sapwood moisture content is always higher than or equal to that of the middle heartwood, as was previously noted by Hinckley et al. (1978).

Table II shows that frost-cracked trees always have a moisture content significantly higher than that of sound trees and that north-south differences are only significant for $Q$. petraea Liebl.

\section{Discussion}

Our results correspond to those of Miller (1987), which underlined the importance of site conditions on frost-crack spatial distribution. Such differences could be seen as a site effect (either a climatic or an edaphic one). Roosen (1956), while studying the winter water status of poplars, stated that the environment was likely to influence tree moisture content: the more water in the soil, the higher the moisture content. In our Bellary plot, for 
example, differences in the moisture contents between sapwood, middle and central heartwoods and between north and south are no longer significant in March; perhaps this is an effect of the spring ascendant flow of sap which modifies water distribution in the bole.

Our data suggest that high sapwood moisture content increases the risk of frost-crack. Site moisture content appears to affect sapwood moisture content.

Winter water status could be considered a predisposing factor, discriminating between frost-cracked trees and sound ones, but also a link, hitherto missing, to explain relations between site and frost-cracking. The high frequency of frost-cracks in trees growing on hydromorphic soil or alongside streams (Heller, 1979) or the aggravating effect of rain or wet weather before frosts could therefore be explained by the high water content of soil in such places.

\section{Conclusion}

Frost-cracked trees had significantly higher stem moisture contents during the winter of 1988 than sound trees. These measurements have been repeated in 3 different forests in central and eastern France, on both species of European oak (Q. robur L. and $Q$. petraea Liebl.) with similar results. Small variations from one month to the next were observed when sampling took place in the same forest.
Since a study of frost-shrinkage of small oakwood samples has shown that tangential shrinkage (the main explanation of frost-crack formation) depends mostly upon moisture content exceeding a threshold, then a difference in winter water status may be a first step towards an explanation of such a defect.

\section{References}

Cinotti B. (1987) Influence de la structure du bois des chênes (Quercus robur $L$. et $Q$. petraea Liebl.) sur leur sensibilité à la gélivure. D.E.A. Sciences du Bois, INRA, Nancy

Cinotti B. \& Tahani N. (1988) Influence de l'humidité du bois des chênes sur leur sensibilité à la gélivure. Actess du Colloque européen de Rhéologie du Bois, Bordeaux, 1988

Heller D. (1979) L'arbre et l'agriculture. Bull. Vulg. For. 5, 16

Hinckley T.M., Lassoie J.P. \& Running S.W. (1978) Temporal and spatial variations in the water status of forest trees. For. Sci. 24, 1-72

Kübler H. (1983) Mechanism of frost-crack formation in trees: a review and synthesis. For. Sci. $29,559-568$

Miller P. (1987) La gélivure des chênes sessile et pédonculé dans le centre de la France. Aspects descriptif, stationnel, technologique et sylvicole. Mémoire de $3^{\theta}$ année ENITEF

Roosen P. (1956) La teneur en eau des peupliers euraméricains de Belgique. Bull. Inst. Agron. Stat. Rech. Gembloux 25, 179-197

Schirp M. (1968) Les gélivures sur les arbres. Forstarchiv 39, 149-154 (translation in Miller, 1987)

Schirp M. \& Kübler H. (1968) Untersuchungen über die kältebedinten längeänderungen kleiner holzproben. Holz als Roh- und Werk 26, 335-341 